University of Wollongong

Research Online

Faculty of Social Sciences - Papers (Archive) Faculty of Arts, Social Sciences \& Humanities

2015

"I 'feel' like I am at university even though I am online." Exploring how students narrate their engagement with higher education institutions in an online learning environment

Sarah Elizabeth O'Shea

University of Wollongong, sarah.oshea@curtin.edu.au

Cathy Stone

University of Newcastle, copaconnect63@gmail.com

Janine Delahunty

University of Wollongong, janined@uow.edu.au

Follow this and additional works at: https://ro.uow.edu.au/sspapers

Part of the Education Commons, and the Social and Behavioral Sciences Commons

Research Online is the open access institutional repository for the University of Wollongong. For further information contact the UOW Library: research-pubs@uow.edu.au 


\title{
"I 'feel' like I am at university even though I am online." Exploring how students narrate their engagement with higher education institutions in an online learning environment
}

\author{
Abstract \\ This article outlines a collaborative study between higher education institutions in Australia, which \\ qualitatively explored the online learning experience for undergraduate and postgraduate students. The \\ project adopted a narrative inquiry approach and encouraged students to story their experiences of this \\ virtual environment, providing a snapshot of how learning is experienced by those undertaking online \\ studies. The study explores what impacted upon students' engagement in this environment and how \\ different facets of their learning experience made a qualitative difference to how individuals enacted \\ engagement. Drawing upon Sharon Pittaway's engagement framework, the article seeks to foreground \\ student voice as the learners define their engagement in learning, the strategies they employed to assist \\ this process and how engagement was enacted at an individual level. The students' reflections presented \\ in this article can be used to inform teaching and learning strategies designed to improve engagement in \\ the online environment within the higher education sector.

\section{Keywords} \\ i, feel, environment, learning, institutions, education, higher, engagement, am, their, like, narrate, students, \\ exploring, online, though, even, university \\ Disciplines \\ Education | Social and Behavioral Sciences

\section{Publication Details} \\ O'Shea, S., Stone, C. \& Delahunty, J. (2015). "I 'feel' like I am at university even though I am online." \\ Exploring how students narrate their engagement with higher education institutions in an online learning \\ environment. Distance Education, 36 (1), 41-58.
}


"I 'feel' like I am at university even though I am online." Exploring how students narrate their engagement with higher education institutions in an online learning environment

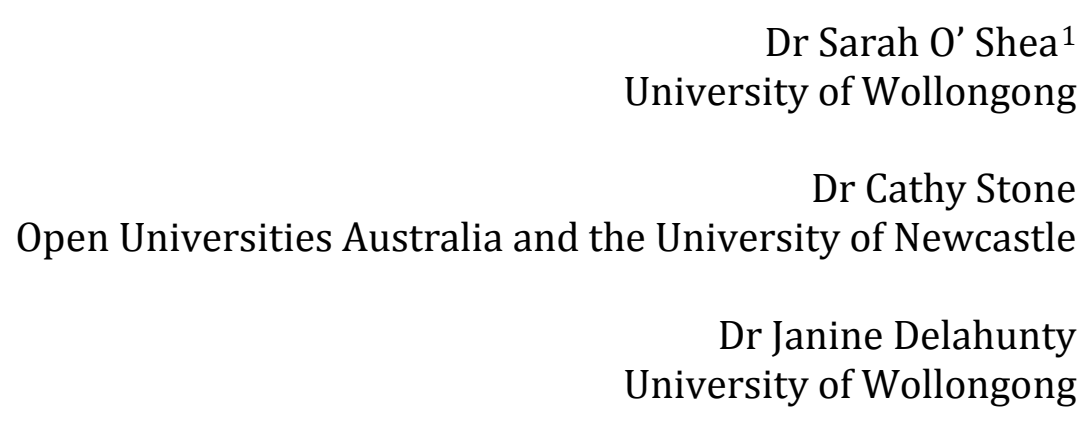

${ }^{1}$ Corresponding author: saraho@uow.edu.au 
1. O'Shea, S., Stone, C., \& Delahunty, J. (in-press, 2015) "I 'feel' like I am at university even though I am online." Exploring how students narrate their engagement with higher education institutions in an online learning environment. Distance Education. Impact Factor: .725. Ranked 109/219 (Education \& Educational Research).

This article outlines a collaborative study between higher education institutions, which qualitatively explored the online learning experience for undergraduate and postgraduate students. The project adopted a narrative inquiry approach and encouraged students to 'story' their experiences of this virtual environment, providing a 'snapshot' of how learning is experienced by those undertaking online studies. This article explores what impacted upon students' engagement in this environment and how different facets of this learning experience made a qualitative difference to how individuals enacted engagement. Drawing upon Pittaway's Engagement Framework (2012), the article seeks to foreground student voice as the learners define their engagement in learning, the strategies they employed to assist this process and how engagement was enacted at an individual level. The students' reflections presented in this article can be used to inform teaching and learning strategies designed to improve engagement in the online environment within the higher education sector.

Keywords: University engagement, online learners, distance education, qualitative inquiry

\section{Introduction}

...it's in cyberspace, as I stated they have no understanding of online students or how to interact with them. There is nothing about us and it's like we are an extension or how it would feel to be an overseas student. I get weather updates and car park info!! (Undergraduate Student, Survey Respondent)

Whilst the on-campus student experience has been the subject of national scrutiny for over a decade (Coates \& Ransom, 2011; James, Krause \& Jennings, 2010; Krause, Hartley, James \& McInnis, 2005; McInnis, James \& Hartley, 2000; Radloff \& Coates, 2010), the experiences of online students remain somewhat ignored within the literature on the tertiary sector (Tyler-Smith, 2006). While no national data is 
available, institutional studies indicate that attrition from the university online environment can be up to $20 \%$ higher than that of face-to-face programs (Carr, 2000; Frankola, 2001; Greenland \& Moore, 2014; Moody, 2004). Recognising that attrition rates do not accurately represent departure from university (Long, Ferrier \& Heagney, 2006) a better understanding of the online learning experience would help to inform universities about ways in which to better engage with this cohort, which may include students who are older, who have had a significant gap in their studies and who have numerous competing demands in their lives (Stone, 2011; Tyler-Smith, 2006). Having access to students from a range of different institutions offered a unique opportunity to research this field. The data generated provides an insight into how online students conceptualise this learning environment and the ways in which these learners might be better supported.

Online delivery reduces many of the barriers associated with attending university; it can be less financially burdensome in terms of travel, relocation or retaining employment and is also not constricted by issues of time or space. Angelino and Natvig (2009) argue that effectively engaging students early in their program is a key strategy to reducing student attrition. Forging positive connections with teaching staff and fellow students has also been demonstrated internationally to play a significant role in student satisfaction, persistence and academic success (Coffman \& Gilligan, 2002; Quinn, 2005). How best to do this in an online environment is still under consideration with limited higher education research focusing on the students themselves (Krause, 2005; Palmer, O’Kane \& Owens, 2009). The study outlined in this article investigated the experience of being an online learner during the transition to this environment. Drawing on interviews $(n=19)$ and surveys $(n=38)$ conducted 
with both undergraduate and postgraduate students who were enrolled in online programs at a number of Australian universities during 2012, this study sought to explore how students narrated their engagement within this environment with reference to the institutions, the staff, other learners and themselves. The following section provides a summary overview of literature in the field of online learning within higher education, with particular reference to online student engagement. This is followed by details of the context and the research design. The qualitative findings are then presented and the article concludes with some recommendations for practice.

\section{Online Learning in Australian Universities}

The steady rise in online learning enrolments in the Australian higher education sector in recent years is reflective of a global trend (Lynch \& James, 2012). These rising numbers are driven in part by student demand for flexible modes of delivery, and by the potential for cost savings, such as travel and other costs which are negated by the virtual environment (Michael, 2012). Michael (2012) points out that implementing elearning technologies has now become a necessity for higher education institutions in Australia to compete within the global market - that such provision is "no longer an option for universities but a requirement in the pursuit of globalization” (p. 157). However, whilst recognised as a necessity for the future, there is also some resistance to embrace new technologies (Saltmarsh \& Sutherland-Smith, 2010; Michael, 2012). As Saltmarsh and Sutherland-Smith (2010) point out "the practice of teaching represents much more than content and course delivery” (p. 15), which raises deeper issues of teacher beliefs, values and practices which may become disrupted when teaching and learning are technology-mediated. Many of the challenges stem from comparisons made between online modes and face-to-face classes. Indeed much 
research is motived by these challenges, such as when face-to-face is the preferred method of teaching and learning (Muller, 2008); when learning online is perceived as inferior (Todhunter, 2013); and when students are reluctant to engage in online activities (Kuyini, 2011). Paradoxically, alongside opportunities afforded by technology for students to engage (Kearsley \& Shneiderman, 1999) there are just as many to disengage (Hughes, 2007). This is in addition to the resistance of some staff to change their face-to-face teaching practices, in order to embrace a different mode of teaching, which also impacts on how academics themselves engage in new environments (Dyment, Downing \& Budd, 2013; Mitchell \& Geva-May, 2009). Indeed Salmon (2005) laments that because on-campus teaching is mainly "an individual and traditional craft", many academics "continue to preserve their existing and familiar pedagogical approaches ... regardless of the introduction of new technology” (p. 202).

Learners may also struggle with the online environment. Issues relating to lower levels of not only technical skills but also time management and motivation are arguably even more crucial in this context. Delahunty (2012) identifies some of the obstacles that online learners encounter as including "uncertainties about interpreting others' attitudes and values, lack of 'real-time' communication, concerns about where an individual perceives they 'fit' in the group, as well as the relatively short duration of the subject intake” (p. 407). Whilst these issues are not confined to online learning, Delahunty (2012) and others (Bowen, 2005; Kearsley \& Shneiderman, 1999; Pittaway, 2012) identify the need to better comprehend the nature of student engagement, particularly given the increased volume of university programs offered in this mode. The following section outlines how student engagement has been 
theorised both within the broader university environment and also, in relation to the online learning environment.

\section{Student engagement and online learning}

Efforts to engage students in their learning in higher education contexts has often focused on what students are doing and the effect of this on academic performance (Carini, Kuh \& Klein, 2006). Learner engagement can be manifested in the development of critical thinking skills, higher grades and a general embracing of learning by taking responsibility and actions to achieve intrinsically motivated goals. However, Bowen (2005) poses the question of what engagement actually means, and what it is that students are engaging with. This is particularly pertinent because improvements in learning are often assumed to occur as the level of engagement shown by students increases (Beldarrain, 2006; Bowen, 2005; Middlecamp, 2005) .While it has been pointed out that educators also need to become engaged in their teaching in order for reciprocal benefits to flourish in both teaching and learning (Dyment et al., 2013; Middlecamp, 2005; Pittaway, 2012), when shifting to online contexts, engagement takes on different manifestations, due to the lack of face-to-face contact and the ways in which teaching and learning is mediated through technology.

Engagement theory was developed by Kearsley and Shneiderman (1999) in response to their teaching experiences in electronic and educational settings. The theory was intended as a conceptual framework for technology-based learning and teaching, with the fundamental premise "that students must be meaningfully engaged in learning activities through interaction with others and worthwhile tasks” (p. 1). The authors

acknowledge that their theory resembles aspects of other theories of learning i.e. 
constructivist, situated learning and andragogy due to an emphasis on interaction in group activities. The basic premise of engagement theory is that 'students must be engaged in their coursework in order for effective learning to occur' (Miliszewska \& Horwood, 2004, p. 1). Engagement theory revolves around three basic principles of promoting student engagement in problem-based collaborative learning activities: relate - create - donate. Relate emphasises group relationships and the interactions and negotiations necessary to establish rapport; create refers to an element of learner control over the choice and development of the task; while donate emphasises the importance of making a contribution to the wider community, in learning tasks which are not necessarily academically-focused, but provide authenticity to the activity.

Approaching engagement from a slightly different perspective is Pittaway’s (2012) Engagement Framework, which is underpinned by four key principles: that engaged staff is a prerequisite for engaging students; that respectful and supportive relationships are crucial; that students be encouraged to take responsibility for their learning; and that scaffolded support and clearly communicated expectations enable students to develop knowledge, understandings, skills and capacities of a high standard (Pittaway, 2012, p. 39). The framework itself comprises “five distinctive yet intersecting non-hierarchical elements of engagement” (p. 39). These are personal, academic, intellectual, social and professional. Personal engagement relates to individuals' levels of confidence, motivation and perseverance whereas academic engagement refers to how students take an active role in their learning. Pittaway refers to intellectual engagement as relating to connection with ideas, concepts, and disciplinary thinking. Social engagement recognises the value of diversity in "views, perspectives, knowledge, understanding, and level of skill, confidence and 
competence” (p. 43), as well as forming positive relationships with peers, tutors and unit coordinators. Lastly, professional engagement (in the context of education) is connections made during professional experience, which extends beyond this to involvement in classroom life, involvement in professional and subject associations, professional development, sharing experiences and learning from others.

This study has drawn upon a broad definition of the term engagement as identified by the Australasian Survey of Student Engagement which identifies how learners are central to the concept of engagement, acknowledging that this concept "focuses squarely on enhancing individual learning and development” (ACER, 2011, p. 17). However, in order to further open-up the survey and interview data, Pittaway’s framework provided further conceptual depth to this analysis. In exploring the nature of engagement, the focus of this study is on how learners themselves narrate their relationship to learning, including their relationship with peers, institutions, staff and also, their student self. To this end, interviews were semi-structured and participants encouraged to describe the unique particularities of their online experiences. The rich descriptive detail offered by participants in interviews, combined with the survey data provides valuable insight into the nature of the online learning for these cohorts, made possible through the qualitative approach taken. Despite a low participation rate limiting the general applicability of this study, this is typical of this type of research, which strives for depth by focussing on specifics rather than generalisations.

\section{Research Design}

\section{Context}


This qualitative study was conducted during 2012 and recruited online students, both undergraduate and postgraduate, affiliated with various institutions. Online students were defined as those who had no required face-to-face component in their program of study; many of the participants lived at quite a distance to the university provider and rarely, if at all, came on campus.

All the undergraduate students were studying entirely online and had enrolled through Open Universities Australia (OUA), an education company that specialises in facilitating online education in partnership with a number of Australian universities. Almost a quarter of a million students have studied through OUA since it began in 1993 (Open Universities Australia, 2013) with 60,000 enrolled students in 2012. Due to the nature of this partnership, most OUA students take subjects from more than one institution in order to meet their degree requirements. The postgraduate students were affiliated with a regional university, which according to the latest annual report (2013) has just over 30,000 students studying across Australian and international locations. This university is strongly focussed on developing online learning, particularly amongst the postgraduate market. It is difficult to estimate the numbers of wholly online learners across the campuses as students may be studying in mixed mode. For the purposes of this study, participants were only recruited from a specific discipline's postgraduate programs as these are offered either wholly online or have no compulsory on-campus attendance.

Students were emailed invitations to participate in a phone interview, with the undergraduate participants also provided with the opportunity of completing a survey with similar questions to those asked during the interview. Both survey and interview 
questions covered topics that included decisions around applying for online studies; experiences of being an online learner as well as milestones and surprises experienced during online studies. A total of 38 students completed the survey, their median age was 40 years with the youngest being 22 years and the oldest 68; the group was predominantly composed of female respondents $(n=32)$ and all were studying undergraduate degrees. Only four survey respondents had completed university studies previously; the majority of the participants had entered university with either school or vocational education qualifications. The following tables indicate the breakdown of survey respondents by degree area and date of commencement:

\section{PLACE TABLE (I) HERE XXXX}

\section{PLACE TABLE (II) HERE XXXX}

Nineteen students agreed to an interview and of these, nine students were studying at a postgraduate level and the remaining ten were all undertaking undergraduate programs. The interviews were conducted between July and September 2012 and in total, 7 males and 12 females agreed to be interviewed. All of the interviews were conducted via phone due to the distances involved. Interview participants varied in age with the youngest interviewee being 25 and the eldest being 71 years old. The median age range of all the interview participants was 43 years old. Two of the undergraduate participants, Eddie (71) and Karl (56), had completed university qualifications prior to entry (in fact Eddie had completed three degrees previously); all the remaining participants had entered their online studies with either vocational qualifications (4); incomplete university studies (2) or a traineeship (2). Of the nine postgraduate participants, eight had entered with prior university qualifications whilst Dave (55) had an Associate Diploma. The following table provides an overview of 
the interview participants including age, degree program, commencement date and highest qualifications prior to commencing online studies:

\section{PLACE TABLE (III) HERE XXX}

\section{Aims}

As mentioned above, this study sought to produce rich detailed understanding about the online learning experience and is based upon the narratives of individual students in this regard. The questions in both the surveys and interviews were deliberately open-ended and participants encouraged to elaborate upon topics. The nature of engagement in this environment was of key interest in this study and so a key focus was the ways in which online students reflected upon their engagement in the online environment with particular reference to students, staff and curriculum. The following section will explain how the findings were analysed, detailing how the data was opened-up and explored inductively.

\section{Data Analysis}

Each interview was transcribed and the transcriptions were imported into NVivo (10) to assist with analysis of the data. Interview text was coded in two phases namely initial coding and then focused coding (Charmaz, 2006). Initial coding was conducted on a line-by-line basis examining text for “analytic import” (p. 42); this process generated 24 thematic codes. This initial analysis was complemented by reflective memos, which strove to ask questions of the data. These memos proved invaluable in the later stages of analysis, when various conceptual lenses were applied to the data. Initial coding enabled the exploration of particular social phenomenon that emerged early in the analysis phase. This initial coding is then a heuristic device enabling greater analytic clarity and involving a large degree of reflection; initial codes relied 
heavily on the text and helped to define what was in the data. Focussed coding further honed these initial codes and organised the data into hierarchical categories derived inductively from the data itself and grounded in the actual experience of the participants. The following data section will explore the data in terms of how engagement was conceived by the participants in relation to other learners, institutions, staff and self.

\section{Presentations of Findings}

The following data explores the facets of engagement that participants reflected upon in interviews and surveys and these are discussed according to the following forms of engagement as identified by Pittaway (2012) namely:

- Social engagement

- Academic and intellectual engagement

- Personal engagement ${ }^{2}$

\section{Social Engagement}

When participants were asked about their level of engagement with other students or what Pittaway (2012) terms as 'social engagement' there was a mixed response. Six of the interviewees and four of the survey respondents alluded to the fact that they perceived connecting socially with their peers in learning as a 'need' or essential to their learning experience. For example, Tania who was completing postgraduate studies explained how: "if there's no connection there with students, you kind of feel a bit isolated if that makes sense" and later on she clarified how: "a lot of us crave

\footnotetext{
${ }^{2}$ Given that these students did not have a professional experience within their online subjects Pittaway's fifth form of engagement (professional engagement) was not included in the analysis of findings.
} 
for that connectivity”. Similarly, one of the survey respondents described missing the university engagement that could only be derived from face to face contact: “[I am] unable to meet face-to-face with tutors and other students to get the 'real' university engagement". When faced with little opportunity to engage socially with other students, three of the interviewees (Yvette, Tina \& Norman) reflected how they had taken the initiative and established Facebook sites to encourage this type of engagement, whilst Dave explained how he had helped to establish a small face to face study group as a number of his colleagues were completing a similar postgraduate course. Yvette indicated that she regarded her age as being the main catalyst for seeking out this connection with others, as she did not feel that the opportunity for social interaction provided by the university sufficed: "what I did is I started a Facebook page for my course and only eight people joined but that's where I got my discussion but I had to do it, I thought, 'Oh, God I'm an old fuddy duddy'”.

Yvette's perception that social connection with other students was something regarded as being extraneous to online studies was shared by other survey respondents and interviewees, some of whom actively avoided this form of engagement with other learners. Eight of the survey respondents regarded communicating with other students as something that simply did not contribute to their learning experience. For example, one survey respondent explained “I didn’t view myself as an online learner, more a correspondence learner, which affects the way in which I communicate with other online learners. I was not after making online 'friends' with other students". Another described how "I guess I have found that I can study well alone and don't need support from other students by joining a Facebook page or something like that. This is probably to do with my age as well as 
being a very independent person”. Three interviewees made similar comments; Ida explained how she avoided social contact with other learners, as this was "not something that I'm looking for". Similarly, Linda stated simply: "I want to do the unit, do the work that I need to do and not worry about everybody else”.

Participants also provided insight into their engagement with teaching staff. Perhaps not surprisingly, these learners had very clear perceptions of what assisted them to feel socially engaged with staff members and what limited this. The factors that impacted negatively on the enactment of social engagement with staff included i) poor online communication ii) non-responsiveness and iii) the "disappearing” lecturer. The first factor referred to a general lack of understanding about how to communicate effectively in an online environment, four interviewees referred to this inability. Whilst Inca and Ana regarded this as simply "poor communication skills” both Neill and Liam suggested that this was a result of lack of experience in the online context. For example, Neill explained how it was necessary to be aware that some lecturers “aren't necessarily familiar with using or confident in using online methods of communication”, which can lead to “...instances where they can come across quite abrasive or, or are quite negative." Similarly, Liam explained that he had encountered some teaching staff who “don't really know how to be a tutor for an online environment, they're probably fine face-to-face...." We can assume that such issues also impacted on the intellectual engagement of students, given the underlying pedagogical nature of this feedback.

Both interviewees and survey respondents also referred to the frustrations associated with not receiving responses from teaching staff in a timely manner. This included 
direct communication via email and also, within the discussion forums. One survey respondent explained the difference between good and bad units of study; the latter defined as "self-service units" which are characterised by "little or no feedback, no discussion and 'don't bother me' tutors". Coupled with this lack of communication was a phenomenon that we termed the "disappearing lecturer", which also negatively impacted on learner engagement. Four of the interviewees provided examples of when the lecturer or tutor would simply disappear from the online subject. For example, Inca who described how:

Sometimes you'd have unusual things happen where they just seem to disappear after, like by 11, 12, week 11, week 12 they just don't come back. I had a couple of experiences like that but I'm not sure where or why that happened...

Neill explained how "In some instances yes, they [the lecturers] just seem to disappear" echoed by Karl who revealed "there was a period of time when there was no communication”. In Eddie’s case his experiences of the “disappearing lecturer” simply led him to adopt the role of tutor in his subject: "I used to sit there and look at their questions and so on and then after a number of days and I came to expect there would be no response... and tell them whatever was needed”.

Participants reported that the lecturers with whom they felt more engaged with were those who i) "transcended" the online environment ii) responded in a timely manner and iii) demonstrated an active and engaged attitude. In achieving the first point, it was those staff who moved beyond a static online delivery to one that involved 
regular video presentations, made themselves available by phone or simply handled "that limitation of communication method" (Neill) that were noted. Not surprisingly, timely response to emails was also perceived as a positive factor in relationships with teaching staff as was being active and engaged in the learning process. Liam explained: “...if the tutor's very active and engaging with students, generally the students are more willing to engage with each other...”. This attitude was also characterised by demonstrating a willingness to "go the extra mile" for students as explained by the following survey respondent: "the tutor was extremely busy she took time out to help me. When I thanked her for her time her response was 'no problems always have time for my students they are the reason I have a job". Lorcan described how his lecturer demonstrated her engagement through assignment feedback, describing how “...she really personalised the actual assessment results. So she said, "Well look, these are your strengths in your assessment tasks and they need to be looked at", do you know what I mean. So it was a really, it was a constructive feedback on what we'd submitted".

\section{Academic and intellectual engagement}

Pittaway (2012) refers to academic and intellectual engagement, which for these participants was often measured through online discussions with peers, some of which were compulsory. This type of communication was somewhat different to social engagement in that it focused on the content of the subject and was regarded as a means to address subject requirements or extend understanding. Noreen explained how the online forums enabled her to learn from other people in her cohort, who were from “different backgrounds and different cultures”. Similarly, Tania reflected how the forums provided the means to learn from others in the group: 
...what I love is the forum...like how people look at things differently in a different dimension you know, and you learn from that, I think that's fabulous I really love that, because you know obviously this group that we're involved with are quite highly intelligent and it's nice to see different dimensions there, different experiences, that's what I love.

Not all the participants viewed the online opportunities for discussion in quite such a positive light. A total of 10 participants (5 interviewees and 5 survey respondents) expressed how they found the forums unhelpful and largely a waste of time, particularly if they were unmediated and /or included large numbers of students. Karl succinctly stated that he did not have time "to blog and chat about nothingness you know"; similarly Eddie explained that there were "a lot of nothings in there". There was a range of frustrations expressed in relation to this type of online communication including poor management of discussions (Ida, Ana \& Leyla) and “inattentive” tutors (Survey respondent), which simply led to this activity as being perceived as “distracting” (Ana) or just a “forum for one-way communication” (Leyla).

Whilst some of the participants dismissed these types of discussions as largely unhelpful, a further seven interviewees and four survey respondents described the opportunities for online discussions as either intimidating or promoting a sense of isolation. For example, Betty, Linda, Yvette and Dave all characterised the virtual chat rooms as simply engendering a sense of loneliness: 
The forums were there and people wrote in them but there was a chat room and all, like I reckon the carpet wore out because all it was, was people entered and people left. (Yvette)

I don't know why, they don't want to go to the chat room, it still is very isolated...so that part is still empty, to me it is still very empty. (Dave)

In terms of course discussion forums, Ida explained how participating could be " $a$ little bit daunting" and Inca confided that she was reluctant to contribute because: "To be very honest, sometimes I don't like to put down you know, something in writing”. Four survey respondents also echoed this sense of intimidation; these forums were not regarded as safe spaces for learning by a significant number of participants:

I have not been brave enough and don't feel computer literate enough to engage with tutorial chat sessions (Survey Respondent)

The discussion forums were a bit daunting; some people were very opinionated and forceful. Tutors pulled them up, but it put many people off. I think sometimes it crossed the social bullying space.(Survey Respondent)

The participants were asked to reflect upon their engagement with the various institutions that they were studying with and by far the biggest obstacle to feeling engaged was a sense of being different to on-campus students. Neill felt that online learners were "a lower priority than on campus students", while one of the survey respondents referred to online learners as "second fiddle" and another described this cohort as "not really having a voice”. Relatively small things such as receiving emails that were irrelevant to their status as online learners or advice that could not be 
actioned in the online environment could convey this sense of being different. As Leyla explained these are the "little things" that distinguish online students from the "norm":

But there are little things too...I asked for help and they said, "Oh you just use your bar code on your student card”, and I don't have a student card, I'm a distance student you know...

Another survey respondent explained how "Some uni's [sic] ... make it very clear you are an online student and do not show the same interest in your learning." When asked about levels of engagement with institutions, fifteen survey respondents explicitly stated that they did not feel engaged with the university in any way. It should be noted here that all of these respondents, bar one, were studying across more than one university. Undoubtedly, such movement between institutions would have contributed to the transience of these relationships. However, three interviewees and two survey respondents reported that they felt more engaged with the higher education company (Open Universities Australia) through which they were enrolled than they did with the university or universities through which they were studying, due to this being the constant body in their learning journey and one which maintained regular contact with them and kept them informed.

I would say, yep, I'm very connected with Open Universities. Probably because that's the thing that is consistent; I've had 3 unis with 3 different $\log$ ons in the past... so I think because that is what is consistent...(Ida) 
I feel more engaged with them ... than I do with [provider] University...(Neill)

A number of students described various strategies that they had implemented in order to create a relationship between themselves and the institution. For example, one of the survey respondents explained: “I project a sense of belonging onto Sun University [pseudonym] which gives me the sense of place and attachment. Think of it like being in a room with a close friend, although neither says anything; you both acknowledge each other's presence”. Another survey respondent described how involvement in organizing a conference provided a sense of engagement, leading to an appearance in the university's yearbook. For Ana, it was being a member of “the Golden T Honour Society which makes me feel good, yeah so I feel you know, pretty engaged with them considering I'm, I'm just an online student”.

\section{Personal engagement}

One of the factors that impacted negatively on the personal engagement of these learners related to both the online technology and the presentation of learning material in the online environment. Even some who regularly used computers in other settings found learning the technology a struggle, which impacted upon their motivation, confidence and perseverance in this domain:

...it was my very first experience to studying online and having that blackboard, and looking at your screen going, "What the ...?”, and,

“Where do I go?”, and, “What do I do?”. I use computers at work and I'm a regular Facebook person and things like that and I've used 
different things over the years and different programs, but just the whole like, “Oh, God, this is really quite different”. (Ida)

Thirteen students voiced negative experiences in relation to both the content and materials of their online courses, referring to 'out-dated' materials, reliance on repetitive formats and poor structure of the online content.

I found that some of the actual course material is probably not up to standard. Some of it has been quite poor - which I think is probably in some way, when we're online students, we're more likely to get sort of poor photocopies, course notes and things like that, more likely to get them as online students than if we were face-to-face students. (Neill)

Whilst Neill did not explain how he arrived at these conclusions, his perception that he was some sort of second-class citizen in the university environment is very obviously articulated. Regardless of their validity, such perceptions can only negatively impact upon learners' motivation in this online environment.

There was surprise expressed at the fact that some online courses consisted of face-toface material put up online with little regard for the very different teaching medium.

...what works in person is not the same as online, so that's been the biggest surprise. I thought it would just be more sort of, more tailor made for it than what it is. (Ana) 
Liam, Eddie and Yvette each expressed surprise and frustration on the self-directed nature of their online experience, which further impacted on how they engaged with content. For example, Yvette explained how she felt that "I really taught myself, I just felt I was teaching myself everything"; similarly Liam described how he perceived that there was a message of "Here's the video, learn from it", which he objected to given the fees he was paying. Whilst the content of the subjects was criticised by some participants, overwhelmingly the flexibility offered by the online medium was received positively. Fourteen interview participants and thirty-one survey respondents indicated that the best part of studying online was the flexibility and the opportunity to work around various professional and family commitments. For some participants, it was simply being able to study in their own space and at times that suited them, as Neill so eloquently summed up: "I quite like studying in my own ugg boots and track suit pants”.

How learners described their own engagement with learning in the online environment and what contributed positively to this on a deeply personal level provides further insight into the nature of personal engagement. As indicated earlier, participants reported differing levels of engagement with the institutions, other learners and staff members so we sought to understand what it was that assisted them to continue in their studies and sustain their interest. By far the most important factor in student engagement related to assignments; good marks were used by learners to gauge their "sense of fit" with the subject. Norman, for example, explained how at school he was variously named “an idiot”; “a dreamer” and the "class clown”, he left in Year 10 to complete a trade and "that's when my drinking career started". 
Returning to education in his mid-forties, Norman described his high of achieving a distinction in one of his subjects, having been told in the "past that I would never cope with higher education and you know, I mean I've been, I've been reading ancient history before the Roman Empire, I've been reading Latin”. Similarly, Tina described "I think really I was daunted, halfway in you know, I sort of realised, 'I can do this', with my results I got two distinctions with a credit." A total of five interviewees and eleven survey respondents reflected upon assignment marks as being a significant indicator of their belonging in the online environment. Receiving good marks in assignments provided evidence that the decision to engage in online learning was appropriate:

I have surprised myself, as I have mostly received credits, distinctions and even a couple of high distinctions. When I first started I told myself all I had to do was pass. I don't know if this is a double edged sword though as now I get disappointed if a mark on an assignment isn't all that flash putting pressure on myself to get even better the next assignment to keep my overall grade up. (Survey Respondent)

Closely associated with receiving good marks on assignments was the actual enjoyment that participants described in relation to learning. This enjoyment was perceived as a personal "high". Many of the quotes indicated a reciprocal relationship between receiving acceptable grades (i.e not failing), acquiring new knowledge and increases in this "love” of learning. 
It is always a nice surprise when passing the units! The best surprise is the knowledge content. I feel that a whole new world has opened up for me. (Survey Respondent)

I'm getting really good marks and love the process whereby the information I am learning is put to immediate use. To the point where I wonder how I managed to bluff my way through before. I engaged with the subjects, even the ones I disliked. (Survey Respondent)

Ten of the survey respondents referred to the joy of learning new knowledge as being one of the most beneficial parts of their online learning experience, echoed by five of the interviewees:

I was just loving every second of it. Learning you know, learning essays and how to write essays, reviewing and it's extremely sort of scary and challenging and yeah, it's wonderful mmm. (Betty)

It's an awesome experience, it really is, you have to be dedicated...like really at the end of the day you are offering amazing opportunities for people like me. (Inca)

Yvette compared her return to study to a "duck jumping in the water" explaining how "I just love, love, love the learning, I loved the having access to the journals, which was just another revelation for me...”

\section{Discussion and Conclusions}


Quotes such as these provide insight into the lived realities of being an online learner, a detailed "snapshot” that responds to Conrad's (2002) call for much deeper examination of what actually occurs for learners, the affective and relational domains of this environment.

In terms of Pittaway's (2012) social engagement, there were differences in the range and type of relationships that learners sought from other participants in their programs. While some perceived a need for engaging with other learners, equally others saw this as an additional burden to their online studies. In some cases it was a strategic focus on outcomes that limited this engagement with other participants online. As one survey respondent explained: "Mostly I stay disengaged from other students. My aim is to get my degree, and selfish as it may sound, engaging with them generally offers me no benefits". Adult learners are known to often display a pragmatic approach to learning, which helps to make sense of such an approach to the online context. For example, Hughes (2007) suggests that as adult learners the student identity may not be the 'dominant' identity, due to the competing demands on time and energies outside of study, which arguably impacts upon levels of engagement in group activities (p. 715).

Adult learning theorists such as Knowles (1980) have identified how adult learners can be both goal orientated and practical arguing that this cohort "experiences a need to learn it in order to cope more satisfyingly with real-life tasks or problems” (p. 44). In a similar vein, Beldarrain (2006) perceives that the instructor in an online environment must adopt a more learner centred approach that includes adopting the role of "partner in learning” rather than simply "facilitator" (p. 149). Online teachers 
must perceive learners as "contributors of knowledge, and thus allow them to participate in the creation of content” (p. 149). However, we would add that this content and interaction needs to be meaningful rather than simply "ticking boxes", such as requiring students to participate in forums or making responses to questions a compulsory component of the course.

For those of us involved in teaching, both online and on-campus, we need to remain cognisant that older learners have much to contribute in terms of their life skills and experiences. To make learning more intellectually or academically engaging in an online context, Collis and Moonen (2005) recommend the adoption of a “contribution-oriented pedagogy” which enables students to contribute content to a subject repository that can be drawn upon by future students. This approach provides a level of recognisable authenticity to the task that may otherwise be lacking and as such, can contribute to academic engagement. So too can learning design which uses appropriate technology to ensure that the online course content and presentation is sufficiently engaging. Simply transferring material used in face-to-face classes onto a learning management system is not sufficient and may contribute to both intellectual and personal disengagement from activities.

Whilst some of the participants in this study reflected upon their learning in a very pragmatic sense, there was evidence that this opportunity to engage in the acquisition of knowledge was also appreciated in an embodied sense, a "love" of learning. The transformative properties of engaging in university studies has been borne out by related research conducted with on-campus students (Stone \& O’Shea, 2012). Whilst little research has focused on the affective domain of the online learning 
environment, Reilly, Gallagher-Lepak and Killion, (2012) identify how most of these learning experiences include a diversity of emotions ranging from fear and loneliness through to elation and surprise. These authors suggest that the challenge for online educators is to "understand affective experiences of online learners and [to] integrate both affective and cognitive aspects of learning into course design” (p. 100). The participants in this study referred to just such a diversity of emotions, the act of undertaking online studies was translated both in terms of the affective and cognitive.

This study has also indicated that it is often the small things that impact upon learners' sense of academic engagement, both interviewees and survey respondents reflecting upon the need for better recognition of their online status. Receiving emails designed for on-campus students or receiving advice that did not reflect their circumstances indicated to this cohort a lack of institutional awareness of, or interest in, their particular needs and requirements. Such recognition needs to extend to the support services for students many of which retain a focus on face-to-face exchanges for example, academic support services or counselling. If universities intend to grow their online numbers then it is necessary to replicate the learning experience for those students who are located in a virtual environment. Whilst some institutions are making inroads in this field, more work needs to be done to avoid online learners identifying themselves as "second class citizens" or "just an online student” (Ana) as inevitably such messages, albeit unintentional, negatively impact upon various forms of engagement (i.e social, personal, intellectual and academic) within this domain.

Overall, what has emerged as being of most significance to the engagement of this particular cohort of students, can be summarised as follows: 
1. High quality courses that are specifically designed for online learning.

2. Online learners being treated just as important as face-to-face learners and communicated with regularly and appropriately.

3. Academics being accessible and responsive online and engaging regularly and positively with students.

4. Student forums can be problematic and often not well moderated - there is a need to ensure good design and responsiveness of the moderator.

5. More assistance with the technology.

This study also points to the fact that we have a lot more to learn about the online learning environment. Teasing out the differences between the online student experience and that experienced by students who come on-campus is difficult. Clearly, a number of these responses such as the joy of receiving a HD in an assignment, prompt and detailed feedback or the disappearing lecturer are not confined to the online environment, but what we do contend is that when such things occur, they are exaggerated for those students who have limited opportunity for faceto-face interaction and who may already feel more isolated or alienated within the environment. As online educators the challenge is remain cognisant that engagement for online learners may be more difficult and require additional or different approaches to forging connections between learners, content, institutions and also, staff.

Hughes (2007) points out that while the technological medium is "more welcoming of diversity" and offers opportunities to engage flexibly, the possibilities of disengaging are multifold. With Australian university student numbers set to increase 
as a result of the demand driven system (Kemp \& Norton, 2014) and the higher costs associated with on-campus university study (Bexley, Daroesman, Arkoudis \& James, 2013) online studies are likely to become more feasible for a growing cohort of students, both young and old, from the perspectives of cost, time and distance. Further research conducted at a multi-institutional or national level that seeks to understand the nature of student engagement from the learners' perspective is required. Broader qualitative analysis that foregrounds student voice would provide deeper understanding about the various factors that influence student engagement in the online context and also provide a basis for implementing strategies designed to both nurture and maximise this engagement.

\section{References}

ACER. (2011). Dropout DNA, and the genetics of effective support. Research briefing, Australasian Survey of Student Engagement, 11, 1-18. Retrieved from www.acer.edu.au

Angelino, L. \& Natvig, D. (2009). A conceptual model for engagement of the online learner. The Journal of Educators Online, 6(1), 1-19. Retrieved from http://search.ebscohost.com/login.aspx?direct $=$ true $\& \mathrm{db}=\mathrm{ehh} \& \mathrm{AN}=48316160 \&$ site $=\mathrm{e}$ host-live

Beldarrain, Y. (2006). Distance Education Trends: Integrating new technologies to foster student interaction and collaboration. Distance Education, 27(2), 139-153. doi: 10.1080/01587910600789498

Bexley, E., Daroesman, S., Arkoudis, S., \& James, R. (2013). University student finances in 2012: A study of the financial circumstances of domestic and international students in Australia's universities. Melbourne: Centre for the Study of Higher Education. Retrieved from http://hdl.voced.edu.au/10707/266786

Bowen, S. (2005). Engaged Learning: are we all on the same page? Peer Review, 7(2), 4-7. Retrieved from http://ezproxy.uow.edu.au/login?url=http://search.proquest.com.ezproxy.uow.edu.au/ docview/216592772?accountid=15112

Carini, R. M., Kuh, G. D. \& Klein, S. P. (2006). Student engagement and student learning: Testing the linkages. Research in Higher Education, 47(1), 1-32. doi: 10.1007/s11162-005-8150-9.

Carr, S. (2000). As distance education comes of age, the challenge is keeping the students. The Chronicle of Higher Education, 46(23), A39-A41. Retrieved from http://search.ebscohost.com/login.aspx?direct $=$ true $\& d b=a 9 h \& A N=2760978 \&$ site $=e h$ ost-live

Charmaz, K. (2006). Constructing grounded theory - A practical guide through qualitative analysis. London, Thousand Oaks, New Delhi: Sage Publications. 
Coates, H., \& Ransom, L. (2011). Dropout DNA, and the genetics of effective support. AUSSE Research Briefings, (11), June 2011, 1-16. Retrieved from http://research.acer.edu.au/ausse/1

Coffman, D. L., \& Gilligan, T. D. (2002). Social support, stress and self-efficacy: Effects on students' satisfaction. Journal of College Student Retention, 4(1), 53-66. doi: 10.2190/BV7X-F87X-2MXL-2B3L

Collis, B., \& Moonen, J. (2005). Collaborative learning in a contribution orientated pedagogy. In J. Howard, L. Boettecher, K. D. Justice, P. Schenk \& G. Berg (Eds.), Encyclopedia of Distance Learning (pp. 277-283). Hershey, PA: Idea Group. doi: 10.4018/978-1-59140-555-9.ch040

Conrad, D. (2002). Deep in the heart of learners: Insights into the nature of online community. Journal of Distance Education, 17(1), 1-19. Retrieved from http://www.jofde.ca/index.php/jde/article/view/133/114

Delahunty, J. (2012). 'Who am I?': Exploring identity in online discussion forums. International Journal of Educational Research, 53, 407-420. doi: 10.1016/j.ijer.2012.05.005.

Dyment, J., Downing, J. \& Budd, Y. (2013). Framing teacher educator engagement in an online environment. Australian Journal of Teacher Education, 38(1), 133-149. doi: 10.14221/ajte.2013v38n1.6.

Frankola, K. (2001). Why online learners drop out. Workforce, 80(10), 53-58. Retrieved from http://search.ebscohost.com/login.aspx?direct $=$ true\&db=a9h\&AN=5338721\&site=eh ost-live

Greenland, S.J., \& Moore, C. (2014). Patterns of student enrolment and attrition in Australian open access online education: A preliminary case study. Open Praxis 6(1), 45-54. doi: 10.5944/openpraxis.6.1.95

Hughes, G. (2007). Diversity, identity and belonging in e-learning communities: Some theories and paradoxes. Teaching in Higher Education, 12(5-6), 709-720. doi: 10.1080/13562510701596315.

James, R., Krause, K., \& Jennings, C. (2010). The first year experience in Australian Universities - Findings from 1994 - 2009. Melbourne: University of Melbourne.

Kearsley, G. \& Shneiderman, B. (1999). Engagement Theory: A framework for technologybased teaching and learning. Retrieved from http://home.sprynet.com/ gkearsley/engage.htm.

Kemp, D., \& Norton, A. (2014). Review of the Demand Driven Funding System Report. Canberra: Australian Government.

Knowles, M. S. (1980).The Modern Practice of Adult Education. From pedagogy to andragogy. (2nd ed.). New York: Cambridge Books.

Krause, K. L. (2005, September). Keynote Paper: The changing of student experience: Who's driving it and where is it going? Paper presented at The Student Experience Conference: Good Practice in Practice, Charles Sturt University:Wagga Wagga, NSW.

Krause, K. L., Hartley, R., James, R., \& McInnis, C. (2005). The First Year Experience in Australian universities: Findings from a decade of national studies. Higher Education Innovation Programme Centre for the Study of Higher Education: University of Melbourne.

Kuyini, A. B. (2011). Exploring the effects of including students' ideas and concerns on their participation in online groups. The Journal of Distance Education, 25(3), 1-13. Retrieved from 
http://search.ebscohost.com/login.aspx?direct=true \&db=ehh\&AN=75153231\&site=e host-live

Long, M., Ferrier, F., \& Heagney, M. (2006). Stay, play or give it away? Students continuing, changing or leaving university study in first year. Melbourne: ACER.

Lynch, G. \& James, R. (2012). Staying relevant and current with online learning in an increasingly global and competitive environment. International Journal of Advanced Corporate Learning, 5(3), 26-28. doi: 10.3991/ijac.v5i3.2171

McInnis, C., James, R., \& Hartley, R. (2000). Trends in the first year experience in Australian universities. Canberra: Department of Education, Training and Youth Affairs.

Michael, K. (2012). Virtual classroom: reflections of online learning. Campus - Wide Information Systems, 29(3), 156-165. doi: 10.1108/10650741211243175

Middlecamp, C. H. (2005). The Art of Engagement. Peer Review, 7(2), 17-20. Retrieved from http://ezproxy.uow.edu.au/login?url=http://search.proquest.com.ezproxy.uow.edu.au/ docview/216609838?accountid=15112

Miliszewska, I. \& Horwood, J. (2004). Engagement theory: A framework for supporting cultural differences in transnational education. Proceedings of the $27^{\text {th }}$ Annual Higher Education Research and Development Society of Australasia, Miri, Sarawak, 223233. Retrieved from http://www.herdsa.org.au/wpcontent/uploads/conference/2004/PDF/P016-jt.pdf

Mitchell, B. \& Geva-May, I. (2009). Attitudes affecting online learning implementation in higher education institutions. Journal of Distance Education, 23(1), 71-88. Retrieved from http://search.ebscohost.com/login.aspx?direct=true $\& d b=e h h \& A N=47506116 \& s i t e=e$ host-live

Moody, J. (2004). Distance education: Why are the attrition rates so high? The Quarterly Review of Distance Education, 5(3), 205-210. Retrieved from http://search.ebscohost.com/login.aspx?direct $=$ true $\& \mathrm{db}=\mathrm{a} 9 \mathrm{~h} \& A N=16304239 \&$ site $=\mathrm{e}$ host-live

Muller, T. (2008). Persistence of women in online degree-completion programs. International Review of Research in Open and Distance Learning, 9(2), 1-18. Retrieved from http://www.eric.ed.gov/ERICWebPortal/detail?accno=EJ801090

Open Universities Australia.(2013). Annual Report 2012. Melbourne, Vic. Retrieved from http://www.open.edu.au/content/documents/annualreports/OUA_Annual_Report_2012.pdf.

Palmer, M., O'Kane, P., \& Owens, M. (2009). Betwixt spaces: student accounts of turning point experiences in the first-year transition. Studies in Higher Education, 34(1), 3754. doi: 10.1080/03075070802601929

Pittaway, S. M. (2012). Student and staff engagement: Developing an engagement framework in a Faculty of Education. Australian Journal of Teacher Education, 37(4), 37-45. doi: 10.14221/ajte.2012v37n4.8.

Quinn, J. (2005). Belonging in a learning community: The re-imagined university and imagined social capital. Studies in the Education of Adults, 37(1), 4-17. Retrieved from http://search.ebscohost.com/login.aspx?direct=true\&db=a9h\&AN=17701642\&site=ehost-live

Radloff, A., \& Coates, H. (2010). Doing More for Learning: Enhancing Engagement and outcomes. Australiasian Survey of Student Engagement. Australasian Student Engagement Report, Victoria: ACER. 
Reilly, J. R., Gallagher-Lepak, S. \& Killion, C. (2012). "Me and my computer": Emotional factors in online learning. Nursing Education Perspectives, 33(2), 100-5. doi: 10.5480/1536-502633.2.100

Salmon, G. (2005). Flying not flapping: a strategic framework for e-learning and pedagogical innovation in higher education institutions. Research in Learning Technology, 13(3), 201-218. doi: 10.1080/09687760500376439.

Saltmarsh, S. \& Sutherland-Smith, W. (2010). S(t)imulating learning: pedagogy, subjectivity and teacher education in online environments. London Review of Education, 8(1), 1524. doi: $10.1080 / 14748460903557613$

Stone, C. (2011, November). Engaging students across distance and place. Paper presented at Measuring and Improving Student Engagement and Experience Conference, Melbourne.

Stone, C \& O’Shea, S. (2012). Transformations and Self-Discovery: Women returning to study. Illinois: Common Ground Publishing.

Todhunter, B. (2013). LOL - limitations of online learning - are we selling the open and distance education message short? Distance Education, 34(2), 232-252. doi: 10.1080/01587919.2013.802402

Tyler-Smith, K. (2006). Early attrition among first time eLearners: A review of factors that contribute to drop-out, withdrawal and non-completion rates of adult learners undertaking eLearning programmes. Journal of Online Learning and Teaching, 2(2), 73-85. Retrieved from http://jolt.merlot.org/Vol2 No2 TylerSmith.htm 